\title{
Influence of temperature and packaging type on quality parameters and antimicrobial properties during Yateí honey storage
}

\author{
Ramón Alejandro MARTÍNEZ1, Natasha SCHVEZOV², Luis Alberto BRUMOVSKY², \\ Amada Beatriz PUCCIARELLI ROMÁN ${ }^{3 *}$
}

\begin{abstract}
Tetragonisca fiebrigi, is a bee of the subfamily Meliponidae traditionally known as Yateí. Its honey differs from the honey produced by Apis mellifera because it is less viscous, more acidic, has sweetness and particular aromas. It is important to know the behavior of yatei honey in different storage conditions, in order to preserve the characteristics of the honey and ensure the product as harmless. The objective was to determine the influence of temperature, packaging type and storage time of Yateí honey on antimicrobial properties, microbial (Total Mesophilic Aerobic and Mold and Yeast Count) and physicochemical parameters (pH, hydroxymethylfurfural (HMF), acidity, moisture content and diastase), with methodology of national and international standards. The antimicrobial effect was variable against strains of the genus Staphylococcus aureus. The most significant microbiological quality levels were Mold and Yeast counts $\left(>10^{2} \mathrm{CFU} / \mathrm{g}\right)$. The physicochemical parameters with the most significant values were acidity ( $\mathrm{t}_{\mathrm{o}}: 42.5 \mathrm{meq}$ acid/ $\mathrm{kg}$ honey), moisture content $\left(\mathrm{t}_{\mathrm{o}}: 26 \%\right)$ and $\operatorname{HMF}\left(\mathrm{t}_{\mathrm{o}}: 3.8 \mathrm{mg} / \mathrm{kg}\right.$ honey). Storage at refrigeration temperature maintained standard values close to Apis mellifera honey during 180 days; whereas at room temperature it was better to maintain antimicrobial power. No significant difference was found between plastic storage containers vs. glass.
\end{abstract}

Keywords: yatei honey; quality; antimicrobial; container; plastic; glass.

Practical Application: Behavior in different storage conditions to preserve the characteristics of the yatei honey.

\section{Introduction}

Yatei bees (Tetragonisca fiebrigi) are small, have no sting, are social, live in perennial colonies and produce honey in a manner similar to the common bee known as Apis mellifera. They belong to the Apoidea superfamily, subfamily Meliponinae (Camargo \& Menezes, 1992; Michener, 2000). About 500 species are known, of which the great majority are in South and Central America; but because the wood mass of the South American continent is decreasing, the amount of stingless bees is decreased as well (Vit, 2005). Particularly, in Argentina they are found in the Provinces of Misiones, Chaco, Formosa and Corrientes (Crane; 1992: Nogueira-Neto, 1970).

The extensive development of beekeeping has generated a productive technology with knowledge developed from the bee management to the commercialization of the product covering the properties of honey, its packaging methods, its stability over time, their storage conditions and their manufacturing systems in order to obtain a safe product for the consumer.

The development of meliponiculture has recently gained momentum as a source of economic resources and as a promoter of biological diversity due to its role in cross-pollination, being responsible of the fertilization of more than $98 \%$ of native trees and shrubs (Heard, 1999). The meliponiculture has a relative advantage over traditional beekeeping because of the low risk that its management represents, they lack of sting, coexist well with the human environment, and the honey has good prices registered in the market. These factors make the activity a good alternative to diversify production of honeys. Although, the practices of traditional management of meliponids or stingless bees today become unacceptable by the existence of new practices of handling of food products (Good Agricultural Practices, Good Manufacturing Practices), and new methodologies for the management of this bee and of the product must be scientifically validated in order to adapt them to existing international standards.

The honey of the meliponids presents significant differences with the honey of Apis mellifera fundamentally in its organoleptic and physicochemical properties, being characteristic its greater moisture content and acidity (Almeida, 2002; Pucciarelli et al., 2014; Souza et al., 2006; Vit et al., 1994, 1998). International and regional honey quality regulations and recommendations have been developed based on honey produced by Apis mellifera. These establish an upper limit of moisture content around 20\%; higher moisture contents allow microbiological proliferation, predisposing the product to fermentation, which is unacceptable for this type of honey (International Honey Commission, 1981;

${ }^{1}$ Módulo de Bioquímica y Farmacia, Facultad de Ciencias Exactas, Química y Naturales, Universidad Nacional de Misiones - UnaM, Posadas, Misiones, Argentina ${ }^{2}$ Facultad de Ciencias Exactas, Química y Naturales, Universidad Nacional de Misiones - UnaM, Posadas, Misiones, Argentina

${ }^{3}$ Laboratorio de Microbiología de Alimentos y Biotecnología "Dr. F. Benassi”, Facultad de Ciencias Exactas, Química y Naturales, Universidad Nacional de Misiones - UnaM, Posadas, Misiones, Argentina

*Corresponding author: mima@fceqyn.unam.edu.ar 
Mercosur, 1994). Meliponid honeys have higher moisture contents (23-30\%) allowing a characteristic fermentation of yatei honey, which is originated in the honey production vessels in the hive increasing acidity (45 to $60 \mathrm{meq} / \mathrm{kg}$ of honey) above limits regulated for Apis mellifera (40 meq / kg of honey) (Almeida, 2002; Souza et al., 2006; Vit et al., 1994).

The high moisture content of meliponid honey means that its handling and conservation conditions must be adequately studied, since its characteristics differ markedly from those of Apis mellifera honey which are very well known. The maintenance of food in suitable conservation conditions makes its properties, organoleptic and nutritional, remain constant until the arrival to the consumer ensuring a palatable and safe product. In addition, adequate conservation conditions also avoid economic losses due to product decomposition and possible food accidents (Jay et al., 2005).

Many activities are currently underway to promote the production of honey from Yatei. In Misiones, Argentina, there are studies that cover ecological, phytogeographic and seasonal aspects that influence the production of honey. Studies have been started to determine their physico-chemical characteristics (Anacleto et al., 2009; Sgariglia et al., 2010; Souza et al., 2006; Vit et al., 1994, 1998), but to date their microbiological quality has not been determined in a systematic and standardized way nor their physico-chemical characteristics and their behavior during storage.

The objective of this work was to determine the influence of temperature, packaging type and storage time of Yateí honey on antimicrobial properties, microbial (Total Mesophilic Aerobic Count and Molds and Yeasts) and physicochemical parameters ( $\mathrm{pH}$, hydroxymethylfurfural (HMF) moisture content, acidity and diastase content), with methodology based on current national and international standards.

\section{Materials and methods}

The sample of honey from yatei was obtained from the central zone of the province of Misiones, selected among the 100 samples from all the province analyzed previously (Dallagnol et al., 2007; Pucciarelli et al., 2009, 2014; Schapovaloff, 2009).

The extraction of honey was made in a manner similar to that used in the traditional process by local producers, by natural runoff and with sterile syringes, avoiding compression of the hive; then the honey sample was stored in a sterile container for homogenization.

In the laboratory, the sample was subsequently fractionated in sterile, glass and polypropylene translucent containers, both with screw caps, placing identical amounts of the honey sample in each container, which were placed under the different storage conditions, ambient temperature $\left(15-38{ }^{\circ} \mathrm{C}\right)$ and refrigerated temperature $\left(7-10^{\circ} \mathrm{C}\right)$.

The initial sample $\left(\mathrm{t}_{0}\right)$ was analyzed immediately. The different bottles were kept closed for 15, 90, 120 and 180 days. The analyses of the samples obtained from the bottles preserved in each condition (type of container, storage temperature) at different times were performed in duplicate. In each sample the
Microbiological Quality Variation was performed by Counting of Total Mesophilic Aerobic microorganisms, using Plate Count Agar medium, $35^{\circ} \mathrm{C}$, incubating $48 \mathrm{~h}$; and Yeast and Mold Counts, using $\mathrm{H}$ and $\mathrm{L}$ agar medium, incubating at $25^{\circ} \mathrm{C}$ for $5-7$ days (International Commission on Microbiological Specifications for Foods, 2000). Variation of the Antimicrobial Activity was performed as well, by agar diffusion method, against four strains of the genus Staphylococcus spp.: Strain 1: Toxin producing strain from meat product. Strain 2: No toxin producing strain, isolated from dairy food, Strain 3: strain ATCC 25923, Strain 4: Strain ATCC6538. Physicochemical parameters analyzed were: $\mathrm{pH}$, moisture content, free acidity, hydroxymethylfurfural (HMF) and diastase activity, according to the methodology of the Argentine Food Code (Argentina, 1998). Analysis were done by duplicate.

\subsection{Statistical analysis of the data}

For the statistical analysis of the influence of the various factors and their possible interaction, we used the Analysis of variance of more than one factor with the statistical package of the program Statgraphics Plus 5.1. Statpoint Technologies Inc. Warrenton VA. USA. A lower mean difference (LSD) test was then performed for the comparison of the factors. Differences were considered significant when $\mathrm{p}<0.05$. Data is presented as media \pm standard deviation.

\section{Results and discussion}

\subsection{Microbiological quality}

\section{Total Mesophilic Aerobic count}

At the time of harvest, $t_{0}$, the sample presented a count of Total Mesophilic Aerobes log 3.55 or $4 \times 10^{3} \pm 4 \times 10^{2} \mathrm{CFU} / \mathrm{g}$, lower than required by European and Mexican regulations for Honey of Apis mellifera honey. The count is higher than those determined in other works for meliponas, which could be because in this experience the sampling was performed in a manner similar to that used by producers and not exclusively with sterile syringes (Dallagnol et al., 2007; Pucciarelli et al., 2009, 2014; Schapovaloff, 2009; Souza et al., 2006). The time, temperature and packaging factors showed effects on the aerobic count for a 95\% confidence level (Table 1). A significant decrease in counts was observed at 120 days storage in all tested conditions (Table 2), with a small count under storage conditions at room temperature in plastic container and a downward trend was maintained at 180 days storage, in all tested conditions.

\section{Mold and yeast counts}

The count of molds and yeasts was at the initial moment log 4.07 or $1 \times 10^{4} \pm 2 \times 10^{3} \mathrm{UFC} / \mathrm{g}$ (Table 2 ), a value that exceeds the quality standards established by the Argentine Food Code and Mercosur for Apis mellifera honey $\left(1 \times 10^{2} \mathrm{CFU} / \mathrm{g}\right)$. The mold and yeast counts showed significant differences for a $95 \%$ confidence level only for the time effect (Table 1), with a decrease in counts at 90 days of storage. After 90 days of storage, in both containers tested at room temperature, no development of mold and yeast colonies in the microbiological controls was evidenced, while in containers kept in refrigeration, the counts remained viable and 
Table 1. Results of three-ways ANOVA to compare the effects of 2 temperatures (Ambient and Refrigerated), Packaging (Glass and Plastic), and Time in the parameters analyzed in yatei honey. Only significant factors are shown $(\mathrm{p}<0.05)$.

\begin{tabular}{|c|c|c|c|}
\hline & MS & $F$ & $\mathbf{P}$ \\
\hline \multicolumn{4}{|l|}{ TMA Count } \\
\hline Packaging & 1.19 & 8.37 & 0.0080 \\
\hline Temperature & 0.67 & 4.75 & 0.0393 \\
\hline Time & 6.33 & 44.59 & 0.0000 \\
\hline \multicolumn{4}{|l|}{ Mold and Yeast Count } \\
\hline Time & $2.02 \times 10^{8}$ & 115.4 & 0.0000 \\
\hline \multicolumn{4}{|l|}{ Acidity } \\
\hline Temperature & 154089.0 & 2318.99 & 0.0000 \\
\hline Time & 25728.3 & 387.20 & 0.0000 \\
\hline Packaging:Temperature & 610.51 & 9.19 & 0.0035 \\
\hline Temperature:Time & 12513.5 & 188.32 & 0.0000 \\
\hline \multicolumn{4}{|l|}{ Humidity } \\
\hline Temperature & 1.82 & 32.54 & 0.0000 \\
\hline Time & 0.44 & 7.77 & 0.0000 \\
\hline Temperature:Time & 0.39 & 7.02 & 0.0001 \\
\hline \multicolumn{4}{|l|}{ pH } \\
\hline Temperature & 1.64 & 81.04 & 0.0000 \\
\hline Time & 0.86 & 42.15 & 0.0000 \\
\hline Temperature:Time & 0.12 & 6.07 & 0.0003 \\
\hline \multicolumn{4}{|l|}{ Diastase } \\
\hline Temperature & 9645.05 & 1241.17 & 0.0000 \\
\hline Time & 27213.29 & 350.19 & 0.0000 \\
\hline Temperature:Time & 1637.65 & 210.74 & 0.0000 \\
\hline \multicolumn{4}{|l|}{ HMF } \\
\hline Temperature & 186.11 & 16.95 & 0.0001 \\
\hline Time & 403.9 & 36.78 & 0.0000 \\
\hline Packaging:Time & 36.12 & 3.29 & 0.0163 \\
\hline Temperature:Time & 88.29 & 8.04 & 0.0000 \\
\hline \multicolumn{4}{|l|}{ AA 2} \\
\hline Temperature & 63.02 & 560.11 & 0.0000 \\
\hline Time & 407.36 & 3621.0 & 0.0000 \\
\hline Temperature:Time & 26.14 & 232.33 & 0.0001 \\
\hline \multicolumn{4}{|l|}{ AA 3} \\
\hline Time & 344.51 & 95.59 & 0.0003 \\
\hline
\end{tabular}

with downward trends. This behavior, although not statistically significant, can be due to the acidic conditions observed after 90 days on the honey preserved at room temperature (Figure 1A), which would determine the non-viability of these microorganisms. At the same time- 90 days- the counts of Mesophilic Aerobic microorganisms also remain viable; this could be due to the existence of spore-forming microorganisms or aerobic populations resistant to the acidic conditions of the matrix. In several studies carried out with yatei honeys, sporulated aerobic and anaerobic microorganisms such as Bacillus spp. and Clostridium spp. were found (Dallagnol et al., 2007; Iurlina \& Fritz, 2005; Kokubo et al., 1984; Nakano et al., 1990; Pucciarelli et al., 2009, 2014; Tisset \& Durand, 1973; Salamanca Grosso et al., 2001; Schapovaloff, 2009; Snowdon \& Cliver, 1996).
Table 2. Variations in Total Mesophylic Aerobic Count and the count of Molds and Yeasts over time according to storage conditions in yatei honey.

\begin{tabular}{|c|c|c|c|c|}
\hline \multirow{2}{*}{ Days } & \multicolumn{2}{|c|}{ Room Temperature } & \multicolumn{2}{|c|}{ Refrigerated Temperature } \\
\hline & Glass & Plastic & Glass & Plastic \\
\hline \multicolumn{5}{|c|}{ Total Mesophylic Aerobic Count } \\
\hline 0 & $4 \pm 3$ & $4 \pm 3$ & $4 \pm 3$ & $4 \pm 3$ \\
\hline 15 & $4 \pm 1$ & $2.8 \pm 0.1$ & $3.8 \pm 0.8$ & $2.95 \pm 0.04$ \\
\hline 90 & $3.6 \pm 0.8$ & $3.1 \pm 0.3$ & $3.9 \pm 0.3$ & $3.7 \pm 0.3$ \\
\hline 120 & $2.1 \pm 0.2$ & $1.4 \pm 0.2$ & $2.2 \pm 0.1$ & $2.0 \pm 0.2$ \\
\hline 180 & $1.7 \pm 0.6$ & $1.6 \pm 0.3$ & $2.1 \pm 0.1$ & $1.99 \pm 0.06$ \\
\hline \multicolumn{5}{|c|}{ Molds and Yeasts } \\
\hline 0 & $4 \pm 3$ & $4 \pm 3$ & $4 \pm 3$ & $4 \pm 3$ \\
\hline 15 & $3.5 \pm 0.5$ & $3.4 \pm 0.6$ & $3.4 \pm 0.3$ & $3.5 \pm 0.1$ \\
\hline 90 & $2 \pm 2$ & 0 & $2 \pm 2$ & $3.2 \pm 0.2$ \\
\hline 120 & $2 \pm 2$ & 0 & $1 \pm 2$ & $2.4 \pm 0.3$ \\
\hline 180 & $1 \pm 1$ & 0 & $0.7 \pm 0.9$ & $1.3 \pm 0.5$ \\
\hline
\end{tabular}
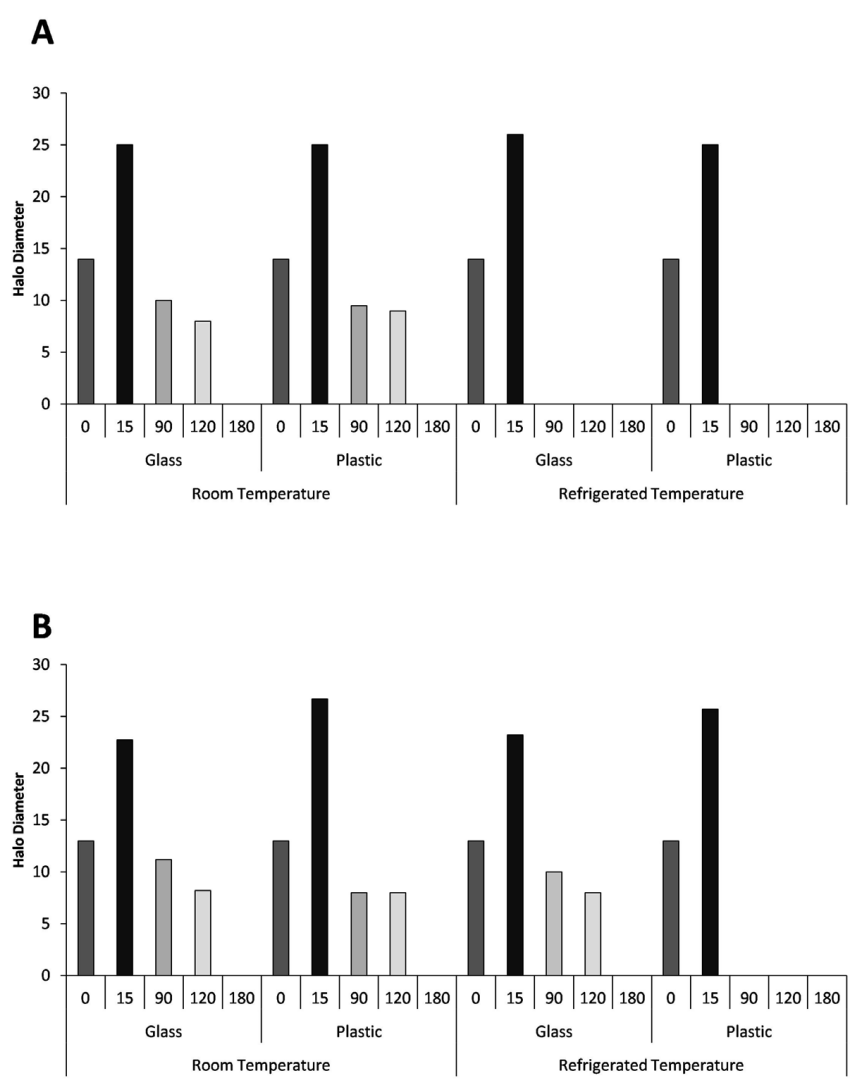

Figure 1. Variation in yatei honey of antimicrobial power over time during storage against (A) Strain2, (B) Strain3.

\subsection{Physico-chemical parameters}

Acidity

Acidity protects honey from microbial colonization and contributes to flavor although largely masked by sugars. The different origins of honeys and the acids in it generate great variability in their acid composition (Cherchi et al., 1994). 
The initial free acidity of the sample at $\mathrm{t}_{\mathrm{o}}$ was $42 \pm 3 \mathrm{meq} \mathrm{acid} / \mathrm{kg}$ honey (Figure 2A) higher than the limit for honey (CAA: $40 \mathrm{meq} / \mathrm{Kg}$ ), but coincident with the different studies performed for meliponid honey (Pucciarelli et al., 2014; Souza et al., 2006; Vit et al., 1994, 1998).

The factors time and temperature showed significant effects at a significance level of 95\% (Table 1). Interactions between time and temperature and between packaging and temperature were also shown to have effect for the same level of significance (Table 1).

At 15 days of storage the acidity of the sample increased in all tested conditions, reaching values close to $50 \mathrm{meq} / \mathrm{kg}$ honey for the samples preserved in refrigeration, and values close to $120 \mathrm{meq} / \mathrm{kg}$ of honey for samples preserved at room temperature (Figure 2A). Later in time the maintenance of the acidity in the samples conserved in refrigeration and increases in the samples conserved at ambient temperature were observed, reaching values close to $200 \mathrm{meq} / \mathrm{kg}$ honey at 180 days of storage.

The acidity of the honey is related to the glucose content of the honey. Glucose is converted by the action of the enzyme
D-glucose oxidase in gluconic acid which constitutes between 70 and $90 \%$ of the acids of honey. This process of transformation produces hydrogen peroxide, an important component of the antimicrobial action of honey (De Mera \& Angert, 2004; Fangio et al., 2007). Studies by Cherchi et al. (1994) showed an increase in acidity during aging of honey by the maintenance of enzymatic activity, regardless of the conservation method. In our work, acidity is dependent of time, but also of the conservation method (packaging and temperature).

The production of acids in honey is given not only by the enzymatic action of the glucose oxidase (De Mera \& Angert, 2004; Fangio et al., 2007), but also by the fermentative processes developed by the microorganisms present in the matrix (Sanz et al., 1995; White, 1975). The cooling temperature reduces both phenomena, causing decreases of the acidity.

\section{Humidity}

The moisture content conditions the color, palatability, flavor and solubility of honey, but fundamentally predisposes honey to microbial colonization, mainly fungal (Finola et al., 2007).
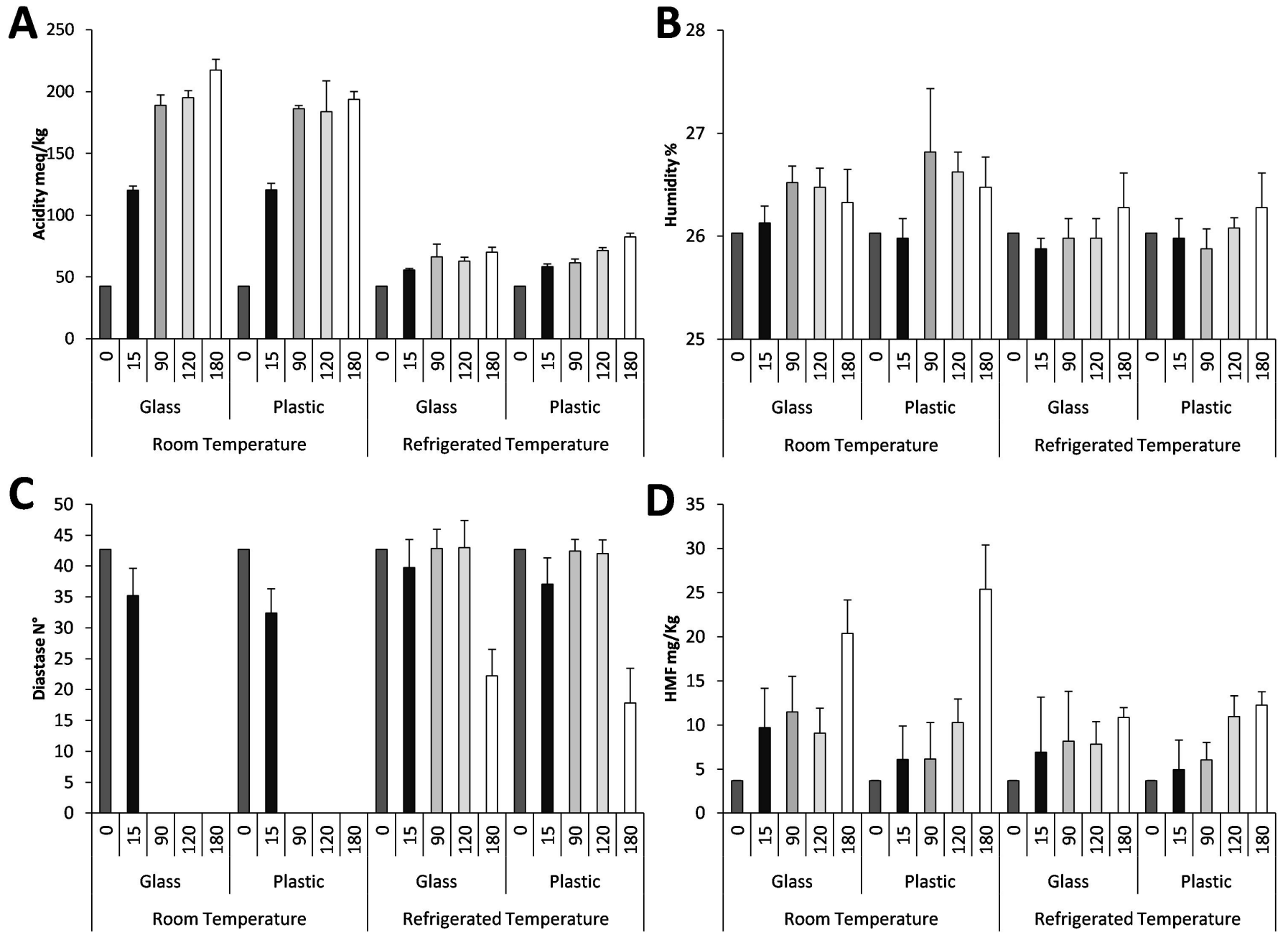

Figure 2.Variation in yatei honey over time during storage of (A) acidity (Acidity meq/kg); (B) Humidity (\%); (C) Diastase Activity (Diastase $\mathrm{N}^{\circ}$ ) and (D) Hydroxymethylfurfural (HMF mg/kg). 
Characteristically, the meliponid honey presents higher humidity than the honey of Apis mellifera (Almeida, 2002; Souza et al., 2006; Vit et al., 1994). At the time of the honey dew ( $\left.t_{\mathrm{o}}\right)$ the sample presented a humidity of $26 \%$, much higher than the $20 \%$ authorized by current regulations (European, Mexican and Mercosur). During storage the humidity of the samples preserved at room temperature increased until reaching at 90 days a value of $26.5 \%$ in glass containers and $26.8 \%$ in plastic containers, values that were not modified at 120 and 180 days of storage (Figure 2B). For samples preserved in refrigeration the humidity values were stable regardless of the type of packaging used (Figure 2B). In honey from meliponids stored at room temperature (approximately $30^{\circ} \mathrm{C}$ ) and at air humidity of $40 \%$, a descent in humidity of the honey was found (Fonseca et al., 2006; Moraes et al., 1989). These studies were done at air humidity below $60 \%$, since above that humidity it was found that honey from Apis mellifera absorbed water (Salamanca Grosso et al., 2001). This could be the case of our work done in yatei honey, since time and temperature had a significant effect on the humidity of the honey (Table 1)

Sanz et al. (1995), and White (1975) described that the fermentation of the honey depends on the initial contamination, the storage time, temperature and the moisture content, this last one being the main factor. The high humidity of the sample (Figure 2B) associated with the high microbiological load (Table 2) and the effect of the temperature, justifies the development of fermentation and the increase of the acidity in the samples preserved at room temperature (Figure $2 \mathrm{~A}$ ).

\section{Diastase}

The three enzymes of major importance in honey are invertase, amylase or diastase and glucose oxidase (Huidobro \& Simal, 1984), both amylase and invertase can be used as indicators of stress or aging of honey, altough different works indicate variations in the convenience in the use of one or the other (Krause \& Krause, 1991; Takenaka \& Echigo, 1974). The regional regulations in Argentina use diastase index as an indicator of aging of honey (Argentina, 1998), which was used in this work. The sample analyzed at the initial time recorded a result of Diastase No. $42 \pm 1$, a value higher than the minimum required by current legislation (Argentina, 1998).

At 15 days of storage, a decrease in enzyme activity was observed in all tested conditions, being more pronounced in samples preserved at room temperature (Figure 2C) which had a total disappearance of the enzymatic activity afterwards (90, 120 and 180 days). This phenomenon is compatible with the modification of the $\mathrm{pH}$ of the samples that determines changes in the enzymatic structure causing the loss of activity.

The decrease in diastase activity was less pronounced in the samples preserved in refrigeration, since the modifications of the properties of these honeys were much smaller. The enzymatic activity presented a decreasing behavior until 180 days of storage, but adapting at all times to the established by the current regulations. These results coincide with different reports (Castro-Vázquez et al., 2008; Ramírez Cervantes et al., 2000; Takenaka \& Echigo, 1974). For the conditions evaluated, time and temperature showed effects for a level of significance of 95\% (Table 1).

\section{Hydroxymethylfurfural}

The heating and aging of honey motivates the production of hydroxymethylfurfural by dehydration of hexoses, which is decomposed into levulinic acid and formic acid, increasing the levels of acidity (International Commission on Microbiological Specifications for Foods, 2001). The reaction is favored by acidic conditions of the sample, accelerating the formation of HMF. This behavior described by several authors (Castro-Vázquez et al., 2008; Ramírez Cervantes et al., 2000; Takenaka \& Echigo, 1974) establishes the usefulness of this indicator to evaluate the aging of honey.

For the evaluated conditions a significant effect was observed for the time-temperature interaction (Table 1). The increase of HMF observed in the samples at 180 days in all tested conditions (room and refrigerated temperature), and did not reach the limits established of $40 \mathrm{mg} / \mathrm{kg}$ in standard honey (Figure 2D). The higher increases in the samples being preserved at room temperature is justified by the temperature -above $30^{\circ} \mathrm{C}$ - and the acidic conditions of the samples, which favors the formation of furfural from sugars.

\section{$p H$}

The $\mathrm{pH}$ recorded in the sample at the time of harvest was $4.02 \pm 0.02$ similar to the values recorded for Apis honeys. These values have been reported in previous studies (Pucciarelli et al., 2009, 2014; Souza et al., 2006; Vit et al., 2004). Time and temperature showed significant interaction (Table 1). At 15 days of storage $\mathrm{pH}$ value underwent a significant decrease in all conditions tested (Table 3). This behavior agrees with the increase of free acidity observed in the same period of time.

Later in time the $\mathrm{pH}$ of the honey samples showed lower values, especially in the samples preserved at room temperature, this effect agrees with the increase of free acidity at room temperature, which showed clear signs of fermentation.

\section{Antimicrobial activity}

The evaluation of the antimicrobial power of the honey against different strains of Staphylococcus aureus showed variable behaviors. Strain 1, wild meat strain, and strain 4, ATCC 6538, showed no sensitivity to the action of honey at the time of roasting or in any of the conditions tested.

Table 3. $\mathrm{pH}$ values in yatei honey during time at different conservation methods.

\begin{tabular}{cccccc}
\hline \multirow{2}{*}{ Days } & \multicolumn{2}{c}{ Ambient } & & \multicolumn{2}{c}{ Refrigerated } \\
\cline { 2 - 3 } \cline { 5 - 6 } & Glass & Plastic & & Glass & Plastic \\
\hline $\mathbf{0}$ & $4.02 \pm 0.02$ & $4.02 \pm 0.02$ & & $4.02 \pm 0.02$ & $4.02 \pm 0.02$ \\
$\mathbf{1 5}$ & $3.4 \pm 0.1$ & $3.30 \pm 0.04$ & & $3.66 \pm 0.03$ & $3.57 \pm 0.07$ \\
$\mathbf{9 0}$ & $3.29 \pm 0.04$ & $3.4 \pm 0.2$ & & $3.9 \pm 0.2$ & $3.8 \pm 0.3$ \\
$\mathbf{1 2 0}$ & $3.6 \pm 0.3$ & $3.6 \pm 0.3$ & & $3.9 \pm 0.2$ & $4.0 \pm 0.2$ \\
$\mathbf{1 8 0}$ & $3.42 \pm 0.06$ & $3.19 \pm 0.02$ & & $3.73 \pm 0.04$ & $3.58 \pm 0.01$ \\
\hline
\end{tabular}


At the moment of honey dew, strains 2 , from dairy products and strain ATCC25923 of Staphylococcus aureus showed inhibition against halos approximately $13 \mathrm{~mm}$ in diameter (Figure 1). This variability of sensitivity to different strains in honey has been documented in several studies (Dallagnol et al., 2007; Miorin et al. 2003; Novak, 2008).

The time factor had an effect on the antimicrobial power for a level of significance of $95 \%$ (Table 1) against both sensitive strains. In addition, strain No. 2 showed effect in temperature for a significance level of $95 \%$ (Table 1).

At 15 days of storage an increase in the inhibitory capacity of the honey was observed against the two sensitive strains, for all storage conditions. This increase in antimicrobial properties may be associated with the appearance of antimicrobial factors related to the decrease in $\mathrm{pH}$ and the increase of the acidity of honey (Bogdanov, 1997; Manrique \& Santana, 2008; Molan, 1992; Perez-Perez et al., 2007; Weston, 2000).

A constant and rapid decrease of the antimicrobial properties was observed, thus, the samples preserved in refrigeration had few inhibitory effects against the strains tested after 90 days of storage, while the samples stored at room temperature maintained their high activity for a longer period. The maintenance of the antimicrobial power in the samples conserved at room temperature reinforces the position of the existence of factors associated to fermentation of the honey that contributes to the antimicrobial activity.

\section{Conclusions}

- According to the values of the microbiological indicators tested, it is necessary to improve the design of the beehives and sampling of honey, in order to minimize the contamination of the product and reduce the microbial counts;

- Packages tested showed no differences for most of the parameters evaluated for a significance level of $95 \%$ up to 180 days of storage. Although, packaging formats should be studied to see costs and sealing systems to improve the product;

- The best condition to maintain the properties of honey is cooling, since it avoids fermentation of the product and no crystallization is observed. For its conservation at room temperature it is necessary to establish a procedure to stabilize the product, such as dehumidification or pasteurization;

- Yatei honey shows its greater inhibitory capacity at 15 days of storage and with the use of the pure product, regardless of the temperature conditions. Storage at room temperature allows the antimicrobial properties to be maintained for a longer period of time;

- The sensitivity of the microorganisms to yatei honey shows a variable behavior according to the evaluated strain.

\section{Acknowledgements}

To the Comité Ejecutivo de Desarrollo e Innovación Tecnológica (CEDIT) of Misiones, Argentina, the honey producers from Misiones and the Foundation of Desarrollo e Investigación Científica y Tecnológica (DINCYT) of Posadas, Misiones, Argentina.

\section{References}

Almeida, D. (2002). Especies de abelha Hymenptera, Apoidea e tipificacao dos meis por elas producidos e marea de cerrado do municiopio de Pirassununga, Estado de São Paulo (Master's thesis). Universidade de São Paulo, Piracicaba.

Anacleto, D. A., Souza, B. A., Marchini, L. C., \& Moreti, A. C. C. C. (2009). Composição de amostras de mel de abelha Jataí (Tetragonisca angustula latreille, 1811). Ciência e Tecnologia de Alimentos, 29(3), 535-554. http://dx.doi.org/10.1590/S0101-20612009000300013.

Argentina. (1998). Metodología analítica oficial de miel del Código Alimentario Argentino (CAA). Ediciones Marzocchi. CAA, Anexo Mercosur, Resol. GMC N 15/94/ MERCOSUR/GMC/RES N 56/99.

Bogdanov, S. (1997). Nature and origin of the antibacterial substances in honey. Food Science and Technology, 30, 748-753.

Camargo, J., \& Menezes, P. (1992). Systematics, phylogeny and biogeography of the Meliponinae (Hymenoptera, Apidae): a mini-review. Apidologie, 23(6), 509-522. http://dx.doi.org/10.1051/apido:19920603.

Castro-Vázquez, L., Díaz-Maroto, M. C., González-Viñas, M. A., de la Fuente, E., \& Pérez-Coello, M. (2008). Influence of storage conditions on chemical composition and sensory properties of citrus honey. Journal of Agricultural and Food Chemistry, 56(6), 1999-2006. PMid:18303839. http://dx.doi.org/10.1021/jf072227k.

Cherchi, A., \& Spanedda, L., Tuberoso, C., \& Cabras, P. (1994). Solid phase extraction and high performance chromatographic determination of organic acids in Honey. Journal of Chromatography. A, 669(1-2), 59-64. http://dx.doi.org/10.1016/0021-9673(94)80336-6.

Crane, E. (1992). The past and present status of beekeeping with stingless bees. Bee World, 73(1), 29-42. http://dx.doi.org/10.1080/000577 2X.1992.11099110.

Dallagnol, A., Schapolavoff, M. E., Garcia, M., \& Pucciarelli, A. B. (2007). Avance de calidad y susceptibilidad antimicrobiana de miel de Yatei. In XI Congreso Argentino de Microbiologia. Córdoba, Argentina: CONICET.

Demera, J., \& Angert, R. (2004). Comparison of the antimicrobial activity of honey produced by Tetragonisca fiebrigi (Meliponinae) and Apis mellifera from different phytogeographic regions of Costa Rica. Apidologie, 35(4), 411-417. http://dx.doi.org/10.1051/apido:2004033.

Fangio, M., Iurlina, M., \& Fritz, R. (2007). Actividad antimicrobiana de mieles del sudeste de la provincia de Buenos Aires frente a Escherichia coli. Revista Argentina de Microbiologia, 39(2), 120-123. PMid:17702261.

Finola, M., Lasagno, M., \& Marioli, J. (2007). Microbiological and chemical characterization of honeys from central Argentina. Food Chemistry, 100(4), 1649-1653. http://dx.doi.org/10.1016/j.foodchem.2005.12.046.

Fonseca, A., Sodré, G., Lopes de Carvalho, C., Oliveira Alves, R., Almeida Souza, B., Silva, M., Oliveira, G., Machado, C., \& Clarton, L. (2006). Qualidade do mel de abelhas sem ferrão: uma proposta para boas práticas de fabricação (Serie Meliponicultura, No. 5). Bahia: Centro de Ciencias Agrarias, Ambientais e Biologicas, UFRB.

Heard, T. (1999). The role of stingless bees in crop pollination. Annual Review of Entomology, 44(1), 183-206. PMid:15012371. http://dx.doi. org/10.1146/annurev.ento.44.1.183. 
Huidobro, J., \& Simal, J. (1984). Parámetros de calidad de la miel, índice de diastasa. Offarm, 3, 705-706.

International Commission on Microbiological Specifications for Foods - ICSMF. (2000). Microorganismos de los alimentos: su significado y métodos de enumeración. Zaragoza: Editorial Acribia S.A.

International Commission on Microbiological Specifications for Foods - ICSMF. (2001). Ecología microbiana de los productos alimentarios: microorganismos de los alimentos. Zaragoza: Editorial Acribia S.A.

International Honey Commission - IHC. (1981). Codex Stan 12-1981: revised codex standard for honey codex stan 12-1981, rev.1 (1987), rev.2 (2001). Retrieved from www.ihc-platform.net/codex2001.pdf

Iurlina, M. O., \& Fritz, R. (2005). Characterization of microorganisms in Argentinean honeys from different sources. International Journal of Food Microbiology, 105(3), 297-304. PMid:16169624. http://dx.doi. org/10.1016/j.jifoodmicro.2005.03.017.

Jay, J. M., Loessner, M. J., \& Golden, D. A. (2005). Modern food microbiology (7th ed). Netherlands: Springer Science \& Business Media.

Kokubo, Y., Jinbo, K., Kaneko, S., \& Matsumoto, M. (1984). Prevalence of spore-forming bacteria in commercial honey. Annual Report of The Tokyo Metropolitan Research Laboratory of Public Health, 35, 192-196.

Krause A, Krause J. Changes in chemicals composition of stored honeydew honey. Acta Alimentaria Polínica. 1991; 17(2): 119-125.

Manrique, A., \& Santana, W. (2008). Flavonoides, actividades antibacteriana y antioxidante de propoleos de abejas sin aguijon, Melipona quadrifasciata, Melipona compressipes, Tetrafonisca fiebrigi y Nannotrigona sp. de Brazil y Venezuela. Zootecnia Tropical, 26, 157-166.

Mercosur. (1994). Reglamento técnico mercosur de identidad y calidad de la miel (Res GMC NNo 015/94). MERCOSUR.

Michener, C. D. (2000). The bees of the world. Baltimore: The Johns Hopkins Univers Press.

Miorin, P., Levy, N. Jr., Custodio, A., Bretz, W., \& Marcucci, M. (2003). Antibacterial activity of honey and propolis from Apis mellifera and Tetragonisca fiebrigi against Staphylococus aureus. Journal of Applied Microbiology, 95(5), 913-920. PMid:14633019. http://dx.doi. org/10.1046/j.1365-2672.2003.02050.x.

Molan, P. C. (1992). The antibacterial activity of honey: the nature of the antibacterial activity. Bee World, 73(1), 5-28. http://dx.doi.org/1 0.1080/0005772X.1992.11099109.

Moraes, R., Benevides, L., \& Menezes, A. (1989). A desumidificação no mel no Brasil. Apicultura \& Polinização., 13, 27-29.

Nakano, H., Okabe, T., Hashimoto, H., \& Sakaguchi, G. (1990). Incidence of clostridium botulinum in honey of various origins. Japanese Journal of Medical Science \& Biology, 43(5), 183-195. PMid:2093130. http:// dx.doi.org/10.7883/yoken1952.43.183.

Nogueira-Neto, P. (1970). A criação de abelhas indígenas sem ferrão (365 p.). São Paulo: Tecnapis.

Novak, P. (2008). Propiedades antimicrobianas de miel de yatei (Tetragonisca fiebrigi). In II Jornada de Iniciación en la Investigación y en la Innovación 2008. Posadas Misiones, Argentina: Comité Ejecutivo de Desarrollo e Innovación Tecnológica. Informe final.

Perez-Perez, E., Rodriguez Malaver, A., \& Vit, P. (2007). Efecto de la fermentación postcosecha en la capacidad antioxidante de miel de Tetragonisca fiebrigi (Latreille, 1811). Revista de la Sociedad Mexicana de Biotecnología y Bioingeniería, 11(1), 14-20.

Pucciarelli, A. B., Schapovaloff, M. E., Kummritz, S., Señuk, I. A., Brumovsky, L. A., \& Dallagnol, A. M. (2014). Microbiological and physicochemical analysis of yateí (Tetragonisca fiebrigi) honey for assessing quality standards and commercialization. Revista de Microbiologia, 46(4), 325-332. PMid:25576417. http://dx.doi. org/10.1016/S0325-7541(14)70091-4.

Pucciarelli, A., Schapovaloff, M. E., Kumritz, M., Señuk, A., Garcia, M. A., \& Brumovsky, L. A. (2009). Caracterización microbiológica y fisicoquímica de miel de yateí en la provincia de Misiones. In Proceedings of The III CICYTAL Congreso Internacional de Ciencia y Tecnología de Alimentos. Cordoba, Argentina: CONICET.

Ramírez Cervantes, M. A., Gonzalez Novelo, S. A., \& Sauri Duch, E. (2000). Efecto del tratamiento térmico temporal de la miel sobre a variación de su calidad durante el almacenamiento. Apiacta, 35(4), 162-170.

Salamanca Grosso, G., Henao Rojas, C. A., Moreno, G. I., \& Luna, A. (2001). Características microbiológicas de las mieles tropicales de Apis mellifera. Cuenca Rural. Retrieved from: http://www.cuencarural. com/granja/apicultura/79053

Sanz, S., Gradillas, G., Jimeno, F., Perez, C., \& Juan, T. (1995). Fermentation problem in Spanish North Coast honey. Journal of Food Protection, 58(5), 515-518. http://dx.doi.org/10.4315/0362-028X-58.5.515.

Schapovaloff, M. (2009). Calidad microbiológica de la miel de yatei para su comercialización: informe final. In III Jornada de Iniciación en la Investigación y en la Innovación 2009. Posadas Misiones, Argentina: Comité Ejecutivo de Desarrollo e Innovación Tecnológica.

Sgariglia, M. A., Vattuone, M. A., Sampietro Vattuone, M., Soberon, J. R., \& Sampietro, D. A. (2010). Properties of honey from Tetragonisca fiebrigi fiebrigi and Plebeia wittmanni of Argentina. Apidologie, 41(6), 667-675. http://dx.doi.org/10.1051/apido/2010028.

Snowdon, J. A., \& Cliver, D. O. (1996). Microorganisms in honey. International Journal of Food Microbiology, 31(1-3), 1-26. PMid:8880294. http://dx.doi.org/10.1016/0168-1605(96)00970-1.

Souza, B., Roubik, D., Barth, O., Heard, T., Enriquez, E., Carvalho, C., Villas Boas, J., Marchini, L., Locatelli, J., Persano Odo, L., Almeida Muradian, L., Bogdanov, S., \& Vit, P. (2006). Composition of stingless bee Honey: setting quality standards. Interciencia, 31(12), 867-875.

Takenaka, L. A., \& Echigo, T. (1974). Changes in enzime activity during storage of honey (Bolletin of the Faculty of Agriculture, Vol. 14, pp. 19-25). Japan: Tamagawa University.

Tisset, C., \& Durand, D. (1973). On the survival of some gram negative, non-sporulated bacteria in commercial honey. Bulletin de l'Academie Veterinaire de France, 46, 191-196.

Vit, P. (2005). Denominaciones de origen de la miel de abejas en Venezuela (28 p). Mérida: APIBA-CDCHT Universidad de Los Andes.

Vit, P., Bogdanov, S., \& Kilchenmann, V. (1994). Composition of Venezuelan honey from stingless bees (Apidae, Meliponinae) and Apis mellifera. Apidologie, 25(3), 278-288. http://dx.doi.org/10.1051/apido:19940302.

Vit, P., Medina, M., \& Eunice Enríquez, M. (2004). Quality standards for medicinal uses of meliponinae honey in Guatemala, Mexico and Venezuela. Bee World, 85(1), 2-5. http://dx.doi.org/10.1080/000577 2X.2004.11099603.

Vit, P., Oddo, L. P., Marano, M. L., \& Salas de Mejias, E. (1998). Venezuelan stingless bee honeys characterized by multivariate analysis of physicochemical properties. Apidologie, 29(5), 377-389. http://dx.doi. org/10.1051/apido:19980501.

Weston, R. J.. (2000). The contribution of catalase and other natural products to the antibacterial activity of honey: a review. Food Chemistry, 71(2), 235-239. http://dx.doi.org/10.1016/S0308-8146(00)00162-X.

White, J. W. (1975). Composition of honey. In E. Crane (Ed.), Honey: comprehensive survey (pp. 157-239). London: Heinemann Edition. 